\title{
Impact of vegetation succession on leaf-litter-soil C:N:P stoichiometry and their intrinsic relationship in the Ziwuling Area of China's Loess Plateau
}

\author{
Zongfei Wang $^{1,2} \cdot$ Fenli Zheng ${ }^{1,3}$
}

Received: 10 September 2019 / Accepted: 4 December 2019 / Published online: 21 May 2020

(C) The Author(s) 2020

\begin{abstract}
Long-term natural vegetation succession plays a substantial role in the accumulation and distribution of plant and soil C:N:P stoichiometry. However, how plant and soil $\mathrm{C}: \mathrm{N}: \mathrm{P}$ relationships or ratios change along with successional stages over a century in the severely eroded areas remain unclear. These were measured over a 100-year natural succession in five successional stages from annual grasses to climax forests. The results show that natural succession had significant effects on carbon $(\mathrm{C})$, nitrogen $(\mathrm{N})$ and phosphorous $(\mathrm{P})$ concentrations in leaf-litter-soil and their ratios in severely eroded areas. Nitrogen concentrations and $\mathrm{N}: \mathrm{P}$ ratios in leaf and litter increased from annual grasses to the shrub stage and then decreased in the late successional forest stages. Leaf P levels decreased from annual grasses to
\end{abstract}

Project funding: This study was financially supported by the External Cooperation Program of Chinese Academy of Sciences (Grant No. 161461KYSB20170013) and Special-Funds of Scientific Research Programs of State Key Laboratory of Soil Erosion and Dryland Farming on the Loess Plateau (Grant No. A314021403-C2).

The online version is available at http://www.springerlink.com.

Corresponding editor: Yanbo Hu.

Fenli Zheng

flzh@ms.iswc.ac.cn

1 State Key Laboratory of Soil Erosion and Dryland Farming on the Loess Plateau, Institute of Soil and Water Conservation, Chinese Acad Sci \& Minist Water Resources, Yangling 712100, Shaanxi, People's Republic of China

2 University of Chinese Academy of Sciences, Beijing 100049, People's Republic of China

3 Institute of Soil and Water Conservation, Northwest A\&F University, Yangling 712100, Shaanxi, People's Republic of China shrub stages and did not significantly change during late successional stages. Litter P concentration decreased in the early successional stages and increased during late successional stages, with no overall significant change. Soil $\mathrm{C}$ and $\mathrm{N}$ concentrations and $\mathrm{C}: \mathrm{N}, \mathrm{C}: \mathrm{P}$ and $\mathrm{N}: \mathrm{P}$ ratios increased with successional stages. Soil $\mathrm{C}$ and $\mathrm{N}$ concentrations decreased with the increasing soil depth. Both were significantly different between any successional stages and controls (cropland) in the upper $10 \mathrm{~cm}$ and $10-20 \mathrm{~cm}$ soil layers. Leaf $\mathrm{N}: \mathrm{P}$ ratios may be used to indicate nutrient limitations and this study suggests that plant growth during the grass stages was limited by $\mathrm{N}$, during the shrub stage, by $\mathrm{P}$, and during the forest stages, by both of $\mathrm{N}$ and $\mathrm{P}$. In addition, there were close correlations between litter and leaf C:N:P ratios, soil and litter $\mathrm{C}$ and $\mathrm{N}$ levels, and $\mathrm{C}: \mathrm{P}$ and $\mathrm{N}: \mathrm{P}$ ratios. These results show that long-term natural vegetation succession is effective in restoring degraded soil properties and improving soil fertility, and provide insights into C:N:P relationships of leaf, litter and soil influenced by vegetation succession stage.

Keywords Ecological stoichiometry · Leaf-litter-soil . Loess Platea $\cdot$ Natural succession $\cdot$ Nutrient elements

\section{Introduction}

Degradation of the environment seriously affects human survival and the sustainable development of social economies (Roberts et al. 2009), and is of concern worldwide. Site restoration, including natural successional and afforestation approaches, is an effective measure to control soil erosion, address ecological degradation, improve environmental quality, and achieve sustainability in ecosystems (Garcia et al. 2002; Zheng 2006; Frouz et al. 2008; Jiao et al. 2012; Deng et al. 2013; Zhao et al. 2015). Secondary successional 
stages, which include grass stages, shrub stages and forest stages, enhance plant diversity and community structure (Letcher 2010), alter plant traits in species (Navas et al. 2010), improve soil nutrient concentrations (Davidson et al. 2007), recover soil caused by erosion (Frouz et al. 2008), increase soil carbon storage (Zhang and Shangguan 2016), and maintain soil fertility (Deng et al. 2013). Understanding the impacts of natural succession on plant and soil nutrients in severely eroded soils is of considerable importance for improving ecological function and providing guidance for reconstruction and rehabilitation of degraded ecological systems.

Ecological stoichiometry concerns the balance of energy and multiple chemical elements in organismal-based systems (Elser et al. 2000; Tian et al. 2010). It is also an effective and useful approach for analyzing the influence of the mass balance of multiple chemical elements in ecological process, for studying the limitations of plant growth (He et al. 2008), and interactions between soil and plants and nutrient cycling (Elser 2006). Most studies have suggested that leaf $\mathrm{N}: \mathrm{P}$ ratios may be used to indicate nutritional limitations for growth (Koerselman and Meuleman 1996; Güsewell 2004). These have been widely accepted and applied to the study of terrestrial ecosystems (Reich and Oleksyn 2004; Han et al. 2005; Zhang et al. 2015). Schreeg et al. (2014) reported that different species have different effects on chemical relationships. Zhang et al. (2015) found that the successional stage was the main factor affecting leaf N:P ratios in a Karst region of China. Richardson et al. (2004) observed that leaf $\mathrm{N}: \mathrm{P}$ ratios varied between 9.2 and 16.0, and increased along a soil chronosequence in temperate rainforests and that $\mathrm{N}$ and $\mathrm{P}$ limitations changed over the succession. Other studies also documented nutrient limitation changes with succession (Davidson et al. 2007; Selmants and Hart 2008; Laliberté et al. 2012; Zhang et al. 2015). In addition, Broadbent et al. (2014) found that P limitation increased during forest succession following slash-and-burn agriculture in the Bolivian Amazon, and this is similar to studies by Du et al. (2011) and Huang et al. (2013). However, McGroddy et al. (2008) and Rastetter et al. (2013) reported that, over succession, plant growth was nitrogen- limited in early stages, phosphorous-limited in middle stages and co-limited by $\mathrm{N}$ and $\mathrm{P}$ in late stages. Therefore, with ecological stoichiometry as a research tool, studies on nutrient distribution, circulation and restriction of $\mathrm{C}, \mathrm{N}$ and $\mathrm{P}$ is of considerable value to understanding the influencing factors and mechanism of ecosystem processes.

The Loess Plateau in China, with an area of $62.4 \times 10^{4} \mathrm{~km}^{2}$, is considered as one of the most seriously eroded areas in the world (Fu et al. 2010). Historically, most of the forests were removed to meet the increasing food needs of a growing population, resulting in severe soil erosion and land degradation. The "Grain-to-Green-Program"
(GTGP) was implemented in 1999 to control soil erosion and restore the ecosystems. The main goal of the GTGP was to transfer low-yielding, steep sloping croplands into grasslands, shrublands or forests (Zheng 2006; Jiao et al. 2012, 2013; Deng et al. 2013). With the development of a site restoration and succession program, plant diversity and community productivity have improved (Wang et al. 2010), soil nutrient levels have increased (Deng et al. 2013), degraded soil properties have recovered (Zhou et al. 2012), soil C storage has increased (Zhang and Shangguan 2016), and soil fertility has been maintained (Zhang et al. 2016). Several researchers have applied methods of plant or soil ecological stoichiometry to investigate nutrient limitations over vegetation succession and have shown that ecological stoichiometry can be used to assess the effects of site restoration in degraded ecosystems (Davidson et al. 2007; An and Shangguan 2010; Du et al. 2011; Laliberté et al. 2012; Huang et al. 2013; Jiao et al. 2013; Rastetter et al. 2013; Chai et al. 2015; Zhang et al. 2015; Zhang and Shangguan 2018). However, plant components and soil ecological relationship changes during secondary successional stages are not particularly clear (Zeng et al. 2017), which limits understanding of nutrient cycling in terrestrial ecosystems.

In recent decades, a wide range of secondary forest landscapes have formed in the Ziwuling area of the Loess Plateau, which is the only natural secondary forest on the Loess Plateau. Studying the long-term natural site succession (100 years or more) can enhance understanding of succession effects on nutrient relationships in degraded ecosystems. In this study, leaf-litter-soil nutrient stoichiometry was investigated across a century of natural succession with five successional stages from annual grasses to climax forest communities. The specific objectives were: (1) to investigate changes in $\mathrm{C}, \mathrm{N}$ and $\mathrm{P}$ concentrations and their stoichiometry in leaf-litter-soil by successional stages; (2) to clarify the limiting nutrient factors of plant growth at each stage; (3) to determine soil profile distribution of nutrients at each stage; and, (4) to analyze the correlations of $\mathrm{C}, \mathrm{N}$ and $\mathrm{P}$ concentrations and their stoichiometry between leaf, litter and soil across the successional stages. The results can provide theoretical basis for planning vegetation restoration and improving the ecological stoichiometry of degraded ecosystems on Chinese Loess Plateau.

\section{Materials and methods}

\section{Study site}

This study was conducted at the Fuxian Observatory for Soil Erosion and Eco-environment $\left(35^{\circ} 44.1^{\prime}-36^{\circ} 23.4^{\prime} \mathrm{N}, 108^{\circ}\right.$ $29.5^{\prime}-109^{\circ} 42.9^{\prime} \mathrm{E}$ ) located in the center of the Ziwuling natural secondary forest of Chinese Loess Plateau (Fig. 1). The 


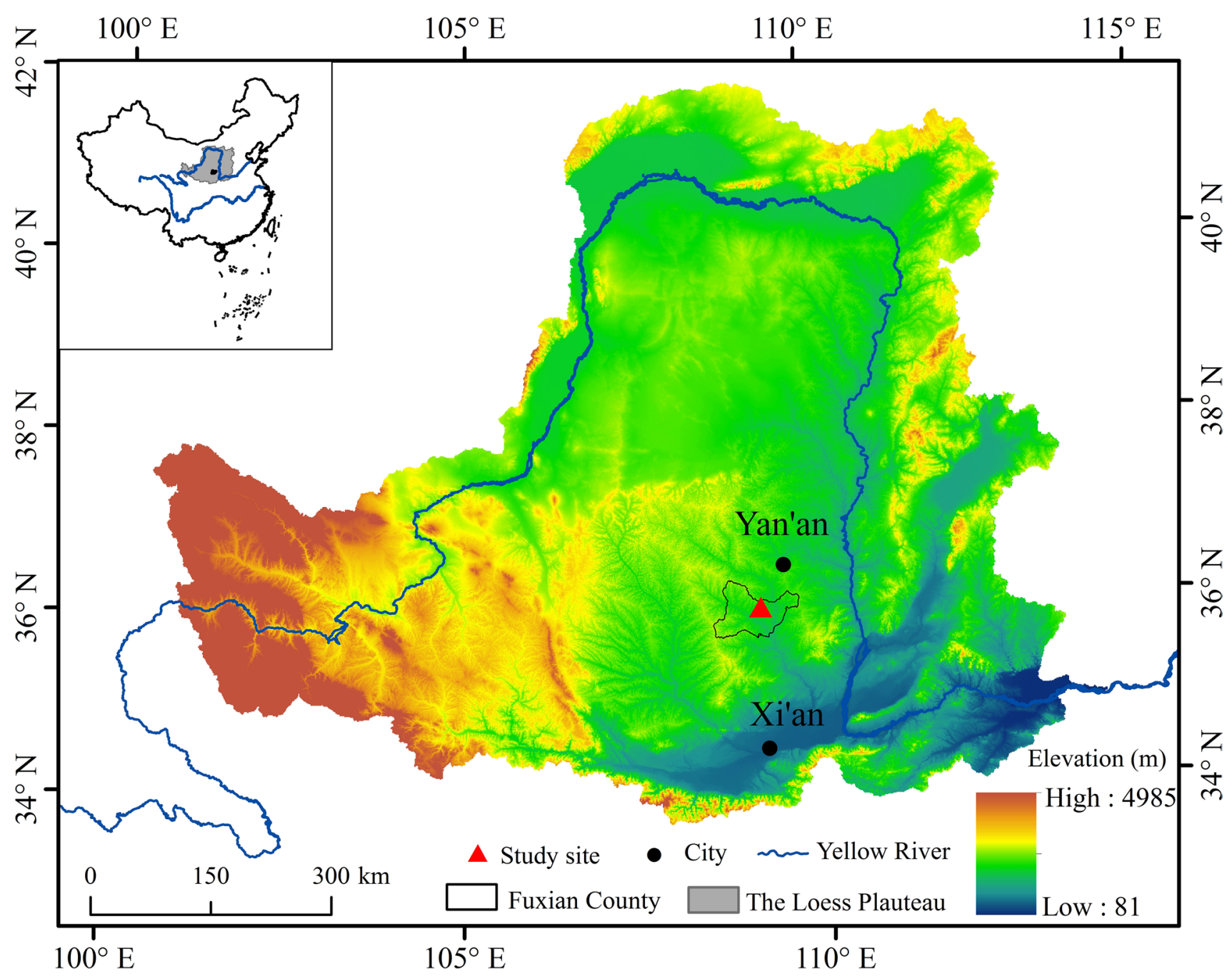

Fig. 1 Locations of the sampling plots

study area is situated in a loess hilly gully region with elevations ranging from 920 to $1683 \mathrm{~m}$ (Zheng 2006). The mean annual temperature is $7.4{ }^{\circ} \mathrm{C}$ and average annual rainfall is $576.7 \mathrm{~mm}$, of which $60 \%$ falls in the rainy season which lasts from June to September. The air relative humidity is $65-70 \%$. The dominant soil is a fine-grained loess, which can be classified as a Calcic Cambisol (USDA NRCS 1999). Soil texture is $28.3 \%$ sand $(>50 \mu \mathrm{m}), 58.1 \%$ silt $(50-2 \mu \mathrm{m})$, $13.6 \%$ clay $(<2 \mu \mathrm{m})$, and the thickness of loess in this region is more than $50 \mathrm{~m}$. Forest canopy closure is more than 0.6 in this area. According to historical records and previous research (Zheng et al. 1997; Kang et al. 2014), most forests were removed and the land cultivated over 100 years ago. Croplands occupied $30 \%$ of the area, and the estimate of soil loss was about $8000-10,000 \mathrm{t} \mathrm{km}^{2} \mathrm{a}^{-1}$. The ephemeral or transitory gully density on hillsides was $20-50 \mathrm{~km} \mathrm{~km}^{-2}$, which reflects severe soil erosion over time. Moreover, the organic horizon was completely removed and loessal parent material exposed to the surface. In 1866-1870, a civil war in this region dispersed populations, and vegetation began to recover and eventually formed a local climax forest largely of Liaotung oak (Quercus liaotungensis Koidz). However, since 1949, there have been several periods of vegetation disturbance, such as the late 1950 (timber and fuelwood needs), 1960-1962 (food demands due to three year's drought disaster), 1966-1976 (the 10-Year Cultural Revolution), and the 1980s (implementing household contract responsibility system) (Wang and Tang 1992). Therefore, at present there are different stages of successions especially, since more than a century has passed; large areas of low-yielding crop filed on steep slopes have converted into grasslands, shrubs and pioneer tree species, and climax forest communities. Furthermore, main pioneer forest is Betula platyphylla Sukaczev; there are two dominant shrub species Sophora viciifolia (Franch.) Skeels and Hippophae rhamnoides Linn., but both does not concur in the same location (Zheng 2006). 
The principal herb species are Artemisia scoparia Waldst. et (Kit.), Artemisia sacrorum (Ledeb.) and Bothriochloa ischaemun (Linn.) (An and Shangguan 2010; Chai et al. 2015). Accordingly, these dominate species were selected to study the impact of vegetation succession on leaf-littersoil C:N:P stoichiometry and their intrinsic relationships.

\section{Soil and plant sampling}

In this study, the approach of substituting "space" for "time" was used, which has been adopted by several researchers (Sparling et al. 2003; An and Shangguan 2010; Jiao et al. 2013; Zhang et al. 2015; Zeng et al. 2017). To select communities representing different successional stages and to determine their ages included the following steps. First, based on previous research (An and Shangguan 2010; Chai et al. 2015) and further field investigation, five stages were selected: annual grass stage (G1), perennial grass stage (G2), shrub stage (S), pioneer forest stage (F1), and climax forest stage (F2). Second, ages of each stage were identified. The early stage $(<20$ years) was easily determined because the "Grain-to-Green" program started in 1999. Identifying the intermediate stage ( $20-75$ years) and later stage ( $>75$ years) included the following steps: (1) the successional age for each site was determined by field investigation and vegetation type; local farmers provided land contracts between themselves and local communities in order to estimate how long farmlands were abandoned to vegetation restoration; (2) past and current village heads were interviewed for information on land use history of each sampling site and to further confirm the successional ages; and, (3) all information was combined to determine the age of each successional stage.

The five vegetation successional stages were approximately 2-, 20-, 55-, 75- and 100-years-old, respectively. Cropland near the sample plots was selected as a control. For each stage or sere, three experimental sites with similar topographical conditions were chosen for sample collection.
In addition, the distance between all experimental sites was approximately $15 \mathrm{~km}$, which reduced the impacts of previous site conditions on the successional process. Leaves and litter of only the dominant species in each stage were collected. Artemisia scoparia Waldst.et (Kit.), was dominant in G1, Artemisia sacrorum (Ledeb.) in G2, Sophora viciifolia (Franch.) Skeels in S, Betula platyphylla Sukaczev in F1 and Quercus liaotungensis Koidz in F2. All shrub and tree species are deciduous. Leaves and soil samples were obtained in late July 2016, when the plants were in a vigorous growth period, and litter samples that lay on the soil surface over multiple years but had not decomposed were collected in late October 2016. Table 1 shows the characteristics of the sample plots of the different successional stages.

For F1 and F2 studies, plots were $20 \mathrm{~m} \times 20 \mathrm{~m}$; for $\mathrm{S}$, plots were $5 \mathrm{~m} \times 5 \mathrm{~m}$, and for G1 and G2, plots were $1 \mathrm{~m} \times 1 \mathrm{~m}$. Each plot had three replicates. Fully expanded leaves were randomly collected from five to ten healthy plants in each plot for the shrub and tree species, and then 10-20 leaves were collected from each shrub or tree, for a total of 50-200 leaves from each plot. For the grasses, stems and leaves were cut from three $0.25-\mathrm{m}^{2}$ sampling sites. All leaf samples were evenly mixed and bagged. Litter samples for each plot were collected from three $1 \mathrm{~m} \times 1 \mathrm{~m}$ squares along diagonal lines, and all litter from these squares was mixed and stored. All samples were transported to the laboratory. Soil samples from the $100-\mathrm{cm}$ profile were collected using a $5-\mathrm{cm}$ diameter soil sampler along an S-shaped route in each plot. Before each sample was collected, the sampler was sterilized with alcohol to ensure samples were free from cross-infection. In addition, the $100-\mathrm{cm}$ profile was divided into six layers $(0-10,10-20,20-40,40-60,60-80$, and $80-100 \mathrm{~cm})$ and samples taken from each layer at five points. Soil samples of each layer were then mixed evenly, stored in a plastic bag and taken to the laboratory.

Table 1 Descriptions of the sample plots at different successional stages

\begin{tabular}{|c|c|c|c|c|c|c|c|}
\hline Successional stages & $\begin{array}{l}\text { Restora- } \\
\text { tion ages/ } \\
\text { (a) }\end{array}$ & Geographic position & Dominant species & Altitude (m) & Slope aspect $\left({ }^{\circ}\right)$ & Slope $\left(^{\circ}\right)$ & Coverage $(\%)$ \\
\hline $\begin{array}{l}\text { Annual grass community } \\
\text { stage (G1) }\end{array}$ & 2 & $\begin{array}{l}\mathrm{N} 36^{\circ} 03^{\prime} 37.98^{\prime \prime} \\
\mathrm{E} 109^{\circ} 09^{\prime \prime} 0.24^{\prime \prime}\end{array}$ & Artemisia scoparia & 1344 & Southeast 35 & 14 & 70 \\
\hline $\begin{array}{l}\text { Perennial grass community } \\
\text { stage (G2) }\end{array}$ & 20 & $\begin{array}{l}\text { N } 36^{\circ} 03^{\prime} 35.94^{\prime \prime} \\
\text { E } 109^{\circ} 09^{\prime \prime} 16.20^{\prime \prime}\end{array}$ & Artemisia sacrorum & 1310 & Southeast 30 & 12 & 80 \\
\hline Shrub community stage (S) & 50 & $\begin{array}{l}\text { N } 36^{\circ} 03^{\prime} 50.82^{\prime \prime} \\
\text { E } 109^{\circ} 08^{\prime \prime} 46.92^{\prime \prime}\end{array}$ & Sophora viciifolia & 1360 & Southeast 15 & 18 & 65 \\
\hline $\begin{array}{l}\text { Pioneer forest community } \\
\text { stage (F1) }\end{array}$ & 75 & $\begin{array}{l}\text { N } 36^{\circ} 03^{\prime} 40.68^{\prime \prime} \\
\text { E } 109^{\circ} 08^{\prime \prime} 57.36^{\prime \prime}\end{array}$ & Betula platyphylla & 1133 & Southeast 50 & 15 & 85 \\
\hline $\begin{array}{l}\text { Climax forest community } \\
\text { stage (F2) }\end{array}$ & 100 & $\begin{array}{l}\text { N } 36^{\circ} 04^{\prime} 56.52^{\prime \prime} \\
\text { E } 109^{\circ} 08^{\prime \prime} 42.54^{\prime \prime}\end{array}$ & Quercus liaotungensis & 1348 & Southeast 20 & 18 & 80 \\
\hline
\end{tabular}




\section{Sample analysis}

Plant samples were oven- dried at $70{ }^{\circ} \mathrm{C}$ for $48 \mathrm{~h}$ to a constant mass and then weighed. The samples were ground to a uniform fine powder using a plant-sample mill (1093 Sample Mill, Foss, Sweden). Soil samples were air- dried and sieved through a $0.25 \mathrm{~mm}$ sieve. The Walkley-Black modified acid-dichromate $\mathrm{FeSO}_{4}$ titration method measured organic $\mathrm{C}$ concentrations of leaf, litter and soil samples (Bao 2000). The Kjeldahl method (KJELTE2300, Sweden) determined total $\mathrm{N}$ concentrations of the samples and total $\mathrm{P}$ levels were quantified by the standard ammonium molybdate method (Bao 2000). Each sample analysis was repeated three times, and the absolute error indicator (less than 5\%) was applied for quality control. $\mathrm{C}, \mathrm{N}$ and $\mathrm{P}$ concentrations were expressed as $\mathrm{g} \mathrm{kg}^{-1}$ on a dry-weight basis. C: $\mathrm{N}$ : P ratios in leaf, litter and soil were calculated as mass ratios.

\section{Statistical analysis}

All results were reported as the means \pm standard errors (SE) and tested for normality of distributions and homogeneity of variances before analysis. One-way ANOVA determined the effects of successional stages on $\mathrm{C}, \mathrm{N}$ and $\mathrm{P}$ concentrations and their stoichiometry of leaves, litter and soil. Two-way ANOVAs analyzed the effects of successional stage, soil depth and their interactions on soil $\mathrm{C}, \mathrm{N}$, and $\mathrm{P}$ concentrations and their stoichiometry. Pearson correlation was used to test the relationship between $\mathrm{C}, \mathrm{N}$ and $\mathrm{P}$ concentrations in leaf, litter and soil. A linear regression analysis tested the relationship between leaf, litter and soil stoichiometric characteristics. All significant differences were shown at $P<0.05$. SPSS 19.0 software (SPSS, Inc., Chicago, IL, USA) was used to perform the statistical analysis.

\section{Results}

\section{Response of leaf and litter $\mathrm{C}, \mathrm{N}$ and $\mathrm{P}$ concentrations to successional stages}

$\mathrm{C}, \mathrm{N}$, and $\mathrm{P}$ levels differed significantly with different successional stages (Fig. 2). Concentrations in leaves were higher than in litter (Fig. 2a-c). In general, leaf $\mathrm{C}$ concentrations increased with successional stage, and in the 75-year-old pioneer forest stage, leaf $\mathrm{C}$ was significantly higher than in other stages. Litter $\mathrm{C}$ levels decreased with successional stages and in the 55-year-old shrub stage was significantly lower than in other stages (Fig. 2a). Leaf $\mathrm{N}$ levels firstly increased and then later decreased, and was highest in the shrub community (55-year-old) and lowest in the annual grass stage (2-year-old) (Fig. 2b), but it was not significantly different among G2, F1 and F2 stages (Fig. 2b).
The dynamic changes of $\mathrm{N}$ levels in litter was similar to that of leaf $\mathrm{N}$ concentrations (Fig. 2b). P levels in leaves significantly decreased over the early seral stages and did not significantly changed in the late successional stages (Fig. 2c). Litter $\mathrm{P}$ concentrations decreased in early grass stages and increased in subsequent stages. In the 20-year-old perennial grass community stage, $\mathrm{P}$ concentrations were significantly lower than in other stages (Fig. 2c).

\section{Changes of leaf and litter $\mathrm{C}, \mathrm{N}$ and $\mathrm{P}$ stoichiometric characteristics with successional stages}

The stage of succession had considerable effects on $\mathrm{C}: \mathrm{N}$, $\mathrm{C}: \mathrm{P}$ and $\mathrm{N}: \mathrm{P}$ ratios in leaves and litter (Fig. 2d-e). C:N ratios in leaf and litter significantly decreased with successional stages, reaching the lowest value in the 55-year-old shrub stage and subsequently increased; were highest in the 2-yearold annual stage (Fig. 2d). Litter C:P ratios were higher than that leaf C:P ratios (Fig. 2e). These increased with the stage of successional, and no significant difference was observed in the 55-year-old (S), 75-year-old (F1) and 100-year-old ages (F2) stages, while litter C:P ratios increased from G1 to $\mathrm{G} 2$ and then decreased (Fig. 2e). N:P ratios in leaves and were opposite to $\mathrm{C}: \mathrm{N}$ ratios in leaves and litter, first increasing in early succession, becoming significantly higher in the shrub stage and then decreasing (Fig. 2f). In general, patterns of leaf C:N:P stoichiometry increased along stage of succession (Table 2).

\section{Distribution of soil $\mathrm{C}, \mathrm{N}$ and $\mathrm{P}$ concentrations in soil profiles}

Figure 3 shows changes of soil $\mathrm{C}, \mathrm{N}$ and $\mathrm{P}$ concentrations with soil depths. Over five successional stages and the cropland control, $\mathrm{C}$ levels were highest in the upper $10 \mathrm{~cm}$ layer, then decreased with increasing depth, remaining stable below $40 \mathrm{~cm}$ (Fig. 3a). The distribution of soil $\mathrm{N}$ was similar to soil $\mathrm{C}$ levels (Fig. 3b). Concentrations of soil $\mathrm{P}$ were relatively stable with increasing soil depth (Fig. 3c). Compared with the control treatment, over five successional stages soil $\mathrm{C}$ and $\mathrm{N}$ concentrations in both the $0-10$ and $10-20 \mathrm{~cm}$ layers were significantly higher and increased with stage of succession. At the $20-40 \mathrm{~cm}$ depth, $\mathrm{C}$ and $\mathrm{N}$ levels were not significantly different between the controls and any succession stage, but increased with stage of succession. Bellow $40 \mathrm{~cm}, \mathrm{C}$ and $\mathrm{N}$ levels were stable. Consequently, changes of soil nutrient concentrations and their stoichiometry with successional stages at $0-10,0-20$ and $0-40 \mathrm{~cm}$ soil depths were analyzed in late section. 

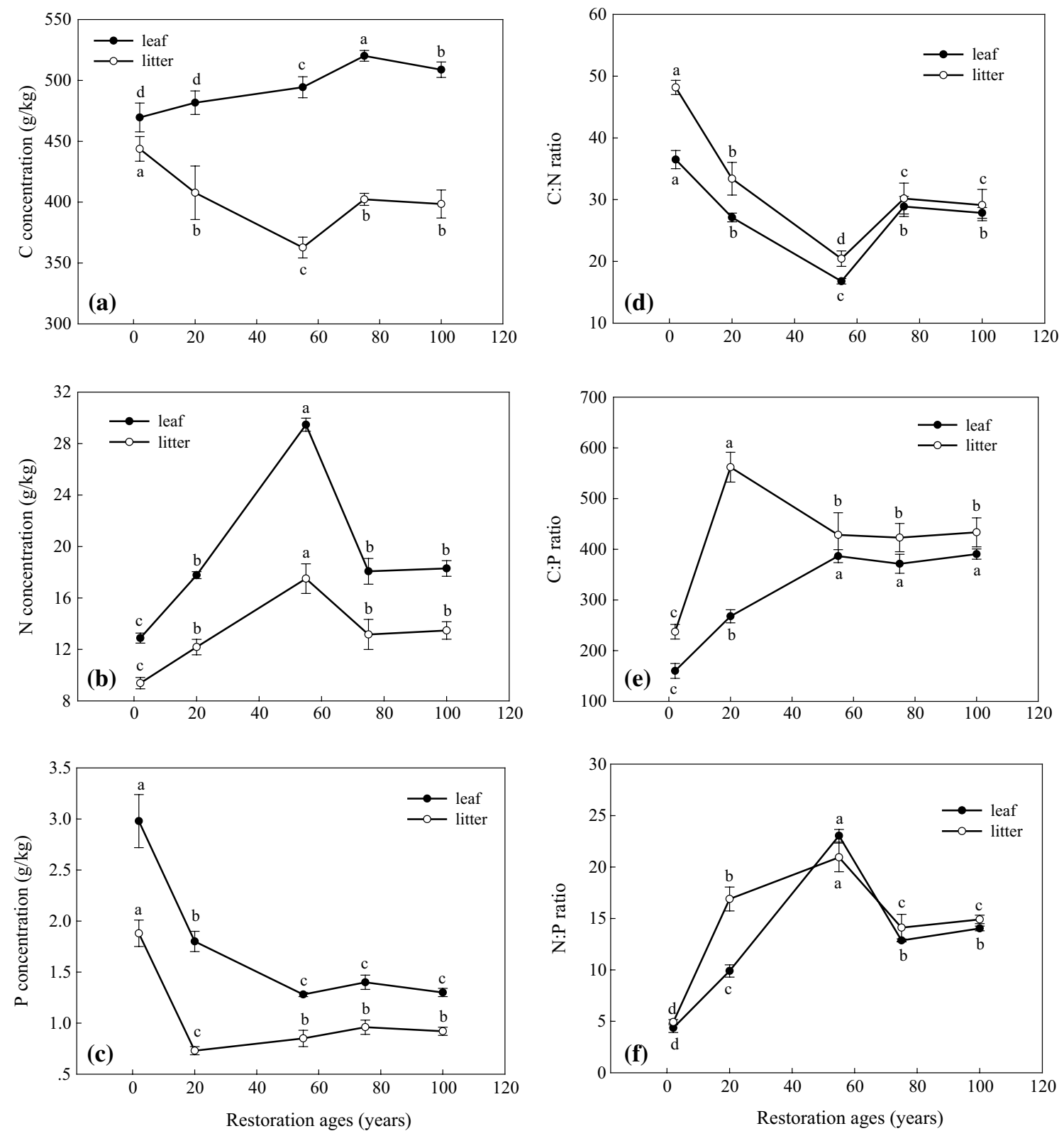

Fig. 2 Change of stoichiometry characteristics of $\mathrm{C}, \mathrm{N}$ and $\mathrm{P}$ in leaf and litter over successional stages. All data are in the form of mean $\pm \mathrm{SE}$. Different lowercase letters indicate significant differences at different vegetation successional stages whether in leaf or in litter $(P<0.05)$

Table 2 C:N:P ratios in leaves, litter and soil at different successional stages

\begin{tabular}{lcllll}
\hline Successional stages & $\begin{array}{l}\text { Restora- } \\
\text { tion ages/ } \\
\text { (a) }\end{array}$ & & Leaves & Litter & \multicolumn{2}{l}{ Soil depth (cm) } \\
\cline { 5 - 6 } & & & & $0-10$ & $0-20$ \\
\hline CL & 2 & $159.0: 4.4: 1$ & $237.3: 4.9: 1$ & $14.1: 1.4: 1$ & $12.8: 1.3: 1$ \\
Annual grass community stage (G1) & 20 & $267.8: 9.9: 1$ & $562.0: 16.9: 1$ & $20.7: 2.0: 1$ & $17.7: 1.7: 1$ \\
Perennial grass community stage (G2) & 20 & $386.6: 22.8: 1$ & $428.4: 20.9: 1$ & $25.8: 2.4: 1$ & $21.2: 1.9: 1$ \\
Shrub community stage (S) & 50 & $371.3: 12.9: 1$ & $423.1: 14.1: 1$ & $25.7: 2.3: 1$ & $20.8: 1.8: 1$ \\
Pioneer forest community stage (F1) & 75 & $390.6: 14.2: 1$ & $433.5: 14.9: 1$ & $31.5: 2.7: 1$ & $24.8: 2.0: 1$ \\
Climax forest community stage (F2) & 100 & & & &
\end{tabular}



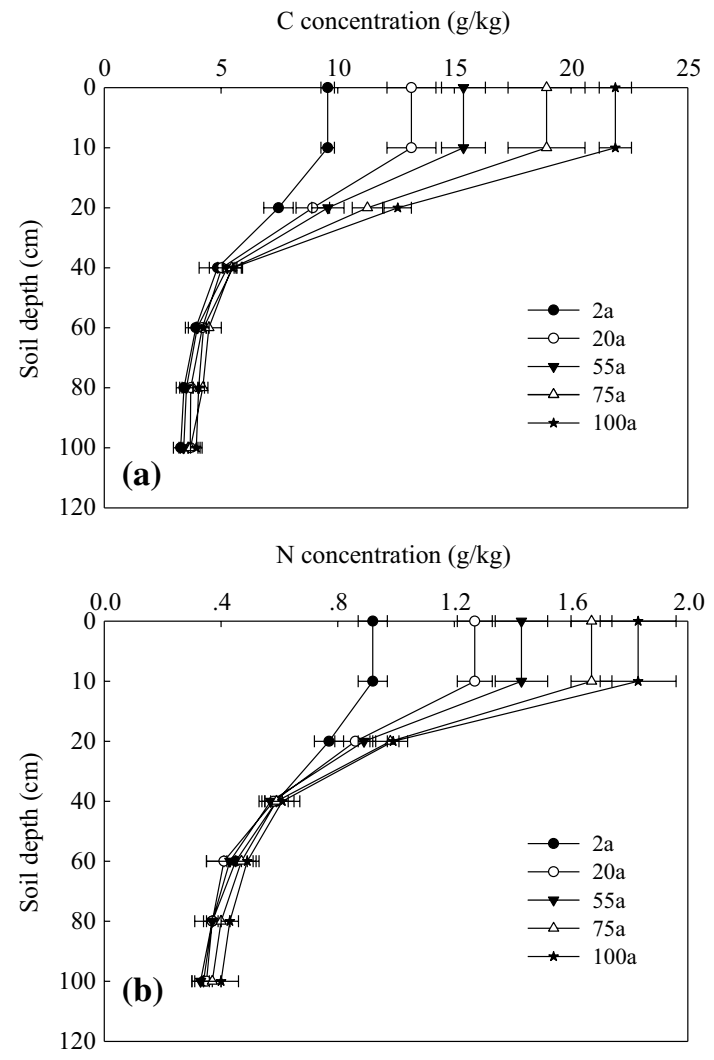

$\mathrm{P}$ concentration $(\mathrm{g} / \mathrm{kg})$

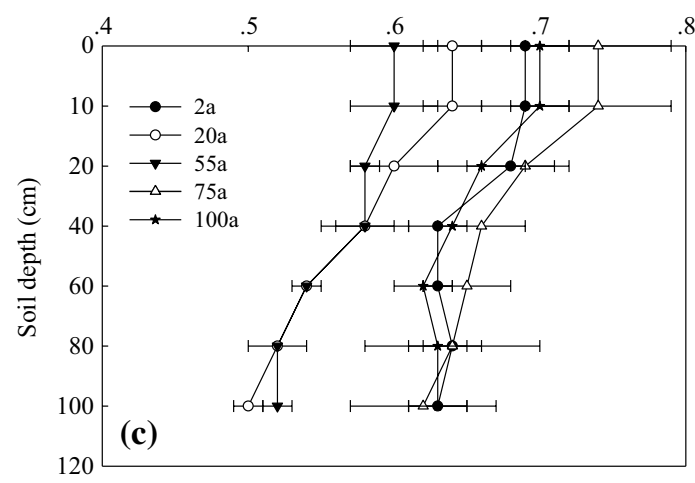

Fig. 3 Vertical profile distribution of soil $\mathrm{C}, \mathrm{N}$ and $\mathrm{P}$ concentrations at different successional stages. CL: crop land; all data are in the form of mean $\pm \mathrm{SE}$

\section{Change of soil $\mathrm{C}, \mathrm{N}$ and $\mathrm{P}$ concentrations with successional stages}

Soil C concentrations in the $0-10,0-20$ and $0-40 \mathrm{~cm}$ layers significantly increased with stage of succession (Fig. 4a). Soil C concentrations over successional stages decreased with increasing of soil depth, ranging from 9.6 to $21.9 \mathrm{~g} / \mathrm{kg}$ in the $0-10 \mathrm{~cm}$ layer, 7.6 to $16.8 \mathrm{~g} / \mathrm{kg}$ in the $0-20 \mathrm{~cm}$ layer and 5.6 to $10.8 \mathrm{~g} / \mathrm{kg}$ in the $0-40 \mathrm{~cm}$ layer. Soil C concentration was highest in the F2 (climax forest community) stage and lowest the controls in all three depths (Fig. 4a). Changes in soil $\mathrm{N}$ with successional stages were similar to soil $\mathrm{C}$ (Fig. 4b), ranging from 0.8 to $1.8 \mathrm{~g} / \mathrm{kg}$ in the upper $10 \mathrm{~cm}$ layer, 0.8 to $1.4 \mathrm{~g} / \mathrm{kg}$ in $0-20 \mathrm{~cm}$ soil depth and 0.6 to $1.0 \mathrm{~g} /$ $\mathrm{kg}$ in $0-40 \mathrm{~cm}$ soil depth. It was highest in the F2 (climax forest) stage and lowest for the controls in these three soil depths. However, soil $\mathrm{P}$ concentrations in the different soil depths $(0-10,0-20$ and $0-40 \mathrm{~cm})$ first decreased from the G1 and G2 grass stages to the shrub stages, increased from the $\mathrm{S}$ stage to the $\mathrm{F} 1$ (pioneer forest stage), and decreased in the climax forest (Fig. 4c).

\section{Changes of soil $\mathrm{C}, \mathrm{N}$ and $\mathrm{P}$ stoichiometric characteristics with successional stages}

The dynamic soil C, N and P stoichiometry changes with vegetation succession in different soil layers are shown in Fig. $4 \mathrm{~d}$ and $\mathrm{f}$. The $\mathrm{C}: \mathrm{N}$ ratios in three soil depths $(0-10$, $0-20$ and $0-40 \mathrm{~cm}$ ) numerically increased with successional stages, and were highest in the climax forest community stage (Fig. 4d). Soil C:P ratios in the $0-10 \mathrm{~cm}$ soil depth was significantly higher than that in the $0-20$ and $0-40 \mathrm{~cm}$ soil depths (Fig. 4e). Soil C:P ratios increased with successional stages and were highest in the climax forest stage in these three soil depths. Changes of N:P ratios by soil depth were similar to changes in soil C:P ratios. In the $0-10 \mathrm{~cm}$ depth, $\mathrm{N}: \mathrm{P}$ ratios in $\mathrm{F} 2$ stage were significantly higher than in other stages, but in the $0-20$ and $0-40 \mathrm{~cm}$ soil depths, there were no significant differences between $\mathrm{S}$ and $\mathrm{F} 2$ stages (Fig. 4f). Soil C:N:P stoichiometry increased over successional stages and were highest in F2 stage and lowest in the controls (Table 2).

The results of two-way ANOVA indicated that both successional stage and soil depth significantly affected soil C, $\mathrm{N}$ and $\mathrm{P}$ concentrations and their ratios. The interactions between successional stage and soil depth significantly affected soil $\mathrm{C}$ and $\mathrm{N}$ concentrations, $\mathrm{C}: \mathrm{N}, \mathrm{C}: \mathrm{P}$ and $\mathrm{N}: \mathrm{P}$ ratios but not $\mathrm{P}$ concentration (Table 3 ).

\section{Relationships between plant and soil nutrients and their stoichiometry}

There were significant correlations between leaf and litter $\mathrm{C}, \mathrm{N}$ and $\mathrm{P}$ concentrations (Fig. 5). Meanwhile, $\mathrm{C}: \mathrm{N}$ ratios in leaves increased linearly with an increase of litter $\mathrm{C}: \mathrm{N}$ ratios $\left(\mathrm{R}^{2}=0.82\right.$ and $\left.P<0.001\right)$ (Fig. 5d). Litter $\mathrm{C}: \mathrm{P}$ ratios were linearly correlated with leaf $C: P$ ratios $\left(R^{2}=0.24\right.$ and $P<0.05$ ) (Fig. 5e). In addition, litter N:P ratios increased linearly with the increase of $\mathrm{N}: \mathrm{P}$ ratios $\left(\mathrm{R}^{2}=0.72\right.$ and $P<0.001$ ) (Fig. 5f).

Based on the above results of soil nutrients profile distribution and changes of soil nutrients with successional stages, the relationship between soil nutrients in $0-20 \mathrm{~cm}$ soil depth and leaf and litter nutrients were analyzed. 

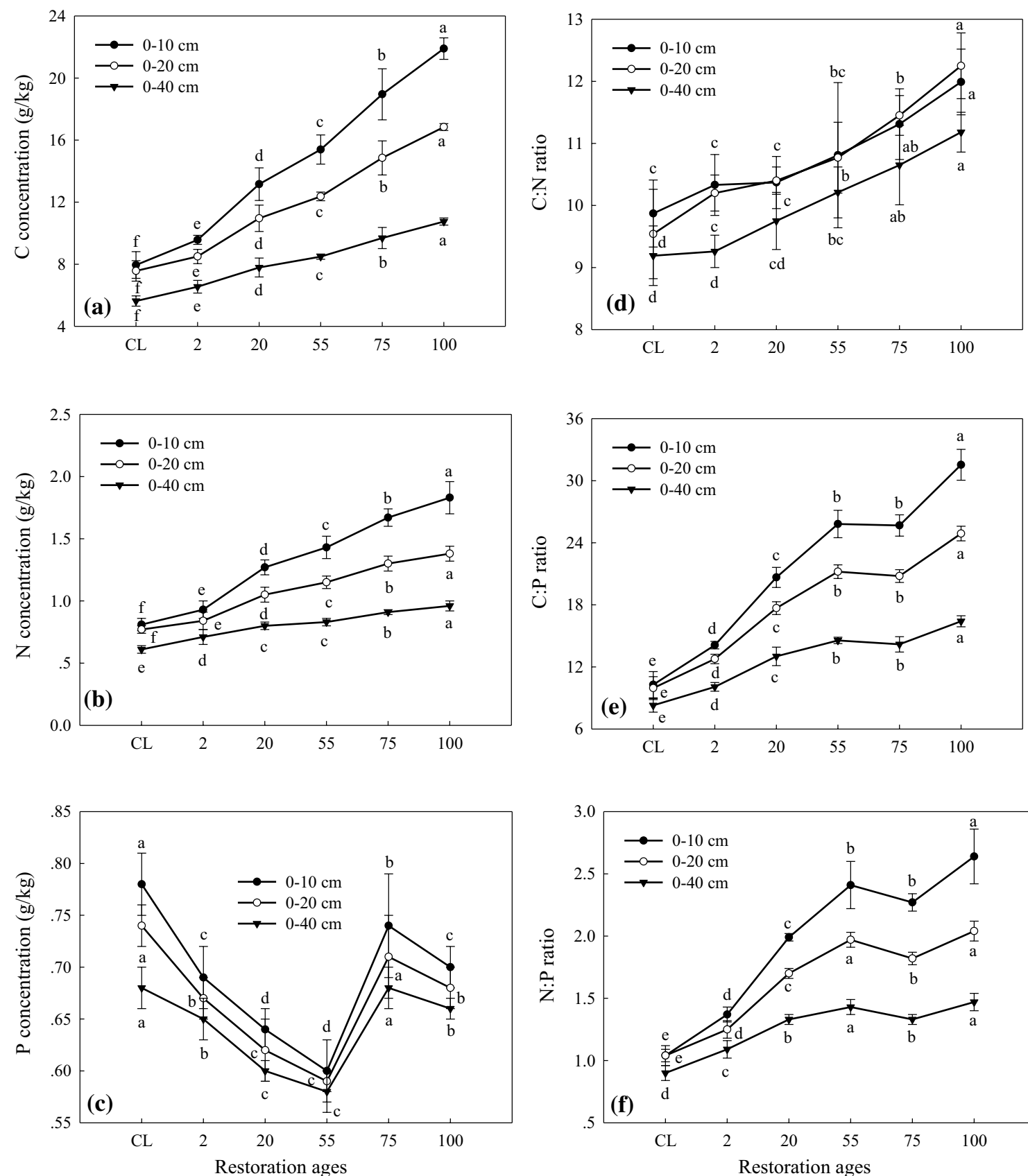

Fig. 4 Stoichiometry characteristics of soil C, N and P at 0-10, 0-20 and $0-40 \mathrm{~cm}$ soil depths by successional stages. CL: crop land; All data are in the form of mean $\pm \mathrm{SE}$; Different lowercase letters indicate

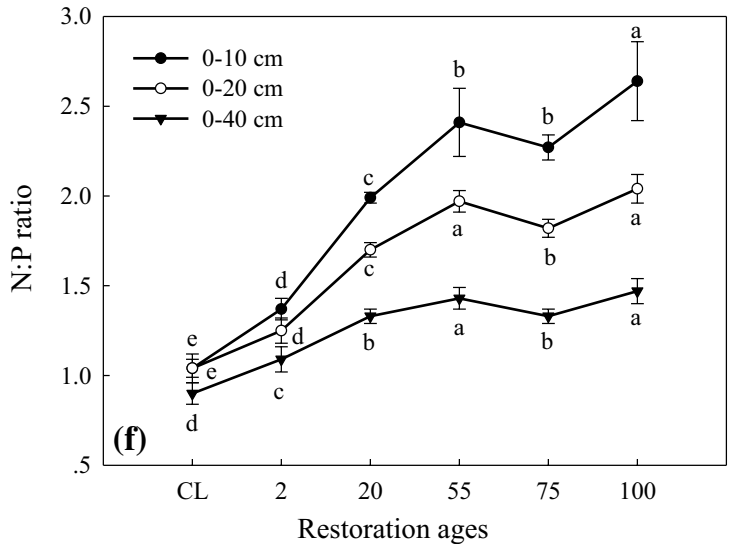

significant differences at different vegetation successional stages in the same soil depth $(P<0.05)$

correlated with soil C:N ratios $\left(\mathrm{R}^{2}=0.05\right.$ and $\left.P=0.247\right)$ (Fig. 6d), and litter C:P ratios were linearly correlated with soil C:P ratios $\left(\mathrm{R}^{2}=0.26\right.$ and $\left.P<0.05\right)$ (Fig. 6e). Additionally, litter N:P ratios increased linearly with an increase in soil N:P ratios $\left(\mathrm{R}^{2}=0.63\right.$ and $\left.P<0.001\right)$ (Fig. $\left.6 \mathrm{f}\right)$. There was a significant positive correlation between leaf and soil $\mathrm{C}$ concentrations in the $0-20 \mathrm{~cm}$ soil depth $\left(\mathrm{R}^{2}=0.62\right.$ and $P<0.001$ ) (Fig. 7a), but the relationships between soil and 
Table 3 Two-way ANOVA results between-subject effects of successional stages, soil depth and their interaction on soil C:N:P ratios

\begin{tabular}{|c|c|c|c|c|c|c|}
\hline \multirow[t]{2}{*}{ Factor } & \multicolumn{6}{|l|}{$F(P)$ value } \\
\hline & $\mathrm{C}$ & $\mathrm{N}$ & $\mathrm{P}$ & $\mathrm{C}: \mathrm{N}$ & $\mathrm{C}: \mathrm{P}$ & $\mathrm{N}: \mathrm{P}$ \\
\hline Successional stage & $\begin{array}{l}155.85 \\
\left(<0.0001^{\mathbb{I}}\right)\end{array}$ & $\begin{array}{l}95.77 \\
(<0.0001)\end{array}$ & $\begin{array}{l}13.33 \\
(<0.0001)\end{array}$ & $\begin{array}{l}54.52 \\
(<0.0001)\end{array}$ & $\begin{array}{l}512.53 \\
(<0.0001)\end{array}$ & $\begin{array}{l}236.59 \\
(<0.0001)\end{array}$ \\
\hline Soil depth & $\begin{array}{l}510.24 \\
(<0.0001)\end{array}$ & $\begin{array}{l}677.79 \\
(<0.0001)\end{array}$ & $\begin{array}{l}10.22 \\
(0.0024)\end{array}$ & $\begin{array}{l}8.94 \\
(0.0043)\end{array}$ & $\begin{array}{l}1727.74 \\
(<0.0001)\end{array}$ & $\begin{array}{l}1511.41 \\
(<0.0001)\end{array}$ \\
\hline $\begin{array}{l}\text { Successional stage * } \\
\text { Soil depth }\end{array}$ & $\begin{array}{l}26.97 \\
(<0.0001)\end{array}$ & $\begin{array}{l}30.43 \\
(<0.0001)\end{array}$ & $\begin{array}{l}0.35 \\
(0.8414)\end{array}$ & $\begin{array}{l}6.39 \\
(0.0003)\end{array}$ & $\begin{array}{l}79.85 \\
(<0.0001)\end{array}$ & $\begin{array}{l}67.05 \\
(<0.0001)\end{array}$ \\
\hline
\end{tabular}

${ }^{\S}$ Indicates the interaction between successional stage and soil depth

"Parentheses is $P$ value leaf $\mathrm{N}$ and $\mathrm{P}$ concentrations were insignificant $(P=0.054$, Fig. 7b) $(P=0.727$, Fig. 7c). Leaf $\mathrm{C}: \mathrm{N}$ ratios were not correlated with soil $\mathrm{C}: \mathrm{N}$ ratios $(P=0.785)$ (Fig. 7d). In addition, soil $\mathrm{C}: \mathrm{P}$ ratios increased linearly with an increase in leaf C:P ratios $\left(\mathrm{R}^{2}=0.75\right.$ and $\left.P<0.001\right)$ (Fig. 7e) and leaf $\mathrm{N}: \mathrm{P}$ ratios were positively correlated with soil $\mathrm{N}: \mathrm{P}$ ratios $\left(\mathrm{R}^{2}=0.45\right.$ and $\left.P<0.001\right)$ (Fig. 7f).

\section{Discussion}

\section{The effect of successional stages on plant $\mathrm{C}, \mathrm{N}$ and $\mathrm{P}$ concentrations and $\mathrm{C}: \mathrm{N}: \mathrm{P}$ ratios}

As a major component terrestrial ecosystem, plants have a vital function in stabilizing the whole system. C, N, P and other elements are essential for plant development (John et al. 2007). Leaf stoichiometric characteristics affect plant growth and reflect their internal characteristics and growth state (Koerselman and Meuleman 1996). Additionally, leaf stoichiometry can reveal the adaptation of plants to the external environment (McIntyre et al. 1999). Plant community succession is a result of the substitution of species leading to changes in community structure, composition and function (Raevel et al. 2012). Due to species composition in various successional stages, nutrient utilization strategies are different, resulting in significant differences in nutrient concentrations and N:P ratios in leaves (Navas et al. 2010). In this study, the differences of dominant species in the five successional stages resulted in differences in $\mathrm{C}, \mathrm{N}$ and $\mathrm{P}$ concentrations and $\mathrm{C}: \mathrm{N}: \mathrm{P}$ stoichiometry in leaves. Leaf $\mathrm{P}$ concentrations in the G1 grass stage was higher than that in the $\mathrm{S}$ (shrub) and $\mathrm{F} 1$ and $\mathrm{F} 2$ forest stages. These results are consistent with studies by Chai et al. (2015) and Zhang et al. (2015). Previous studies showed that the rapid growth of plants requires the synthesis of large amounts of protein and RNA, and this requires a high $\mathrm{P}$ concentration (Elser et al. 2003). Kazakou et al. (2006) also observed that in the succession of abandoned farmlands in the Mediterranean area, early successional species had high $\mathrm{P}$ concentration and relatively high growth rate, and late successional species had longer leaf life. He et al. (2008) also reported that $\mathrm{P}$ concentrations in woody plants were significantly lower than in herbaceous plants. Reich and Oleksyn (2004) and Sardans and Peñuelas (2013) found that plants with long life cycles and slow growth rates had lower $\mathrm{P}$ concentrations than those with shorter life cycles and rapid growth rates. Leaf $\mathrm{N}$ concentrations in the shrub stage were significantly higher than that in other stages, because this stage is characterized by Sophora viciifolia (Franch.) Skeels, a nitrogen-fixing species that utilizes atmospheric $\mathrm{N}_{2}$. Our study has reported that the concentrations of $\mathrm{C}, \mathrm{N}$ and $\mathrm{P}$ in litter were lower than those of plant leaves over all successional stages. This is consistent with the results of Zeng et al. (2017). A possible reason is that leaves transfer nutrients to other plant tissues before senescence (Schreeg et al. 2014). In addition, this disbursement improves nutrient utilization rates and adaptation to the environment (Drenovsky and Richards 2004). In this study, litter $\mathrm{N}$ concentrations first increased and then decreased during the succession process. The change in litter $\mathrm{N}$ was similar to leaf $\mathrm{N}$ concentrations. Takashima et al. (2004) reported that rapid plant growth requires more nitrogen consumption to participate in photosynthesis, and higher $\mathrm{N}$ transfer rates leads to the reduction of $\mathrm{N}$ in litter. In this study, higher growth rates by annual grasses may be the reason that litter $\mathrm{N}$ concentrations were lower than that in other stages.

Research by Güsewell (2004) indicated that deficiencies in $\mathrm{N}$ and $\mathrm{P}$ can be reflected in changes in plant growth. Therefore, leaf $\mathrm{N}: \mathrm{P}$ ratios can be used as one of the indices to estimate nutrient limitations (Koerselman and Meuleman 1996; Güsewell 2004). Güsewell (2004) reported that the threshold of leaf $\mathrm{N}: \mathrm{P}$ ratios were 10 and 20: when the $\mathrm{N}: \mathrm{P}$ ratio was $>20$, plant growth was P-limited, and when the ratio was $<10$, plant growth was $\mathrm{N}$-limited. When the N:P ratio was between 10 and 20, plant growth was limited by both N and P. Thus, based on the Güsewell (2004), the limiting nutrient factor in each successional stage has been identified in this research. In the annual and perennial grass stages (G1 and G2), plant growth was N-limited, whereas it was 

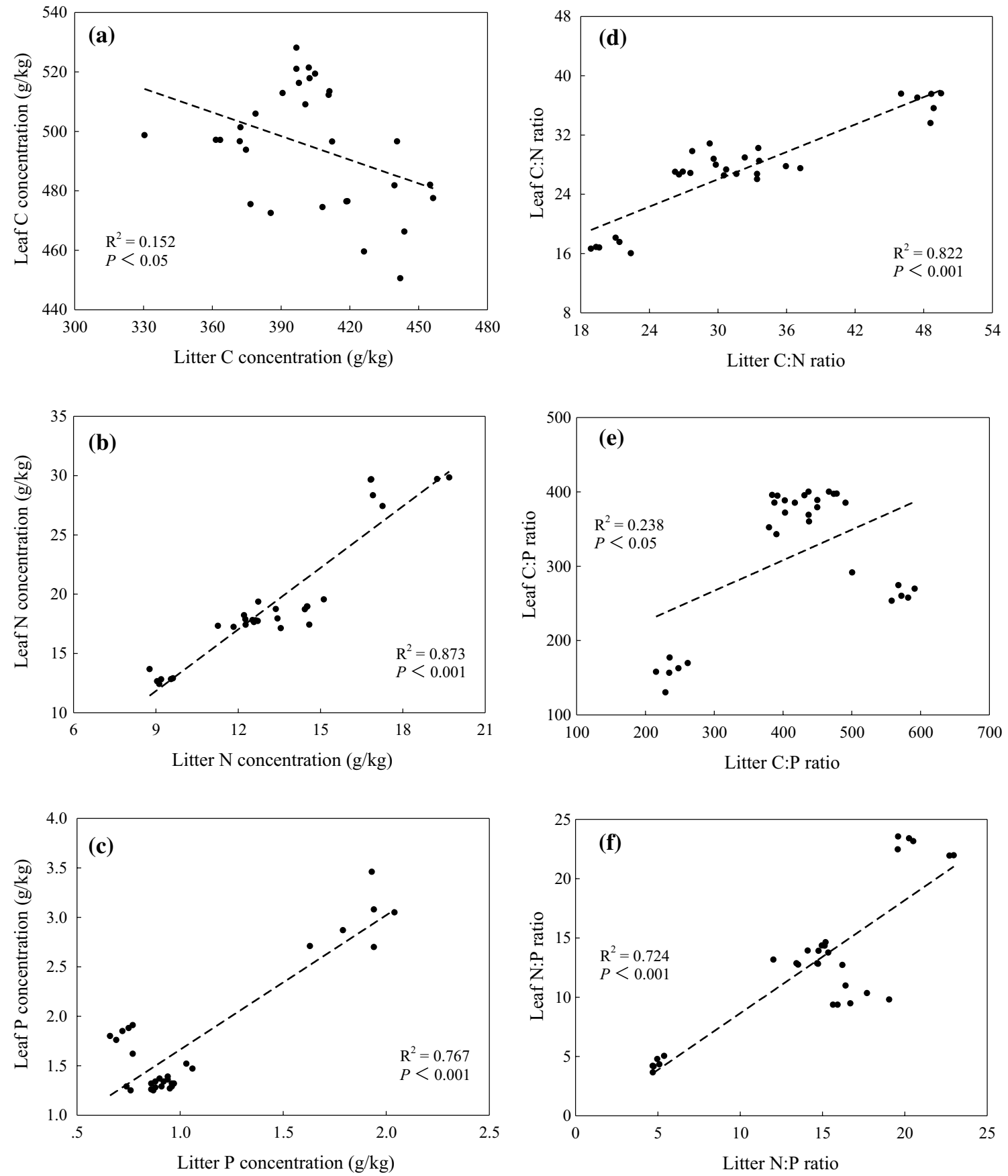

Fig. 5 Correlations between leaf and litter C:N:P stoichiometric characteristics by successional stages

P-limited in the shrub stage (s). In the pioneer and climax forest stages ( $\mathrm{F} 1$ and $\mathrm{F} 2$ ), growth was limited by both $\mathrm{N}$ and $\mathrm{P}$. This is consistent with the results reported by Rastetter et al. (2013). There are several possible reasons for this. The first is related to utilization approaches to obtaining $\mathrm{N}$ and $\mathrm{P}$ elements. Soil $\mathrm{P}$ is mainly derived from the weathering of rocks, which is a long-term biogeochemical cycle, and its utilization is influenced by soil $\mathrm{pH}$ value (Turrión et al. 2000). There are various ways to acquire $\mathrm{N}$ elements (Reich and Oleksyn 2004), and $\mathrm{N}$ in litter is easier to mineralize and release than that of $\mathrm{P}$ (Güsewell 2004). In early successional stages, the release of $\mathrm{P}$ element from soil parent material is a result of surface water erosion, making it easier accumulate $\mathrm{P}$ than later successional stages due to increased vegetation cover. As succession proceeds, the demand for nutrients also increase, resulting in insufficient $\mathrm{P}$, which is caused by the lack rate of $\mathrm{P}$ to be significantly greater than that of N. Secondly, the shrub stage is characterized by 

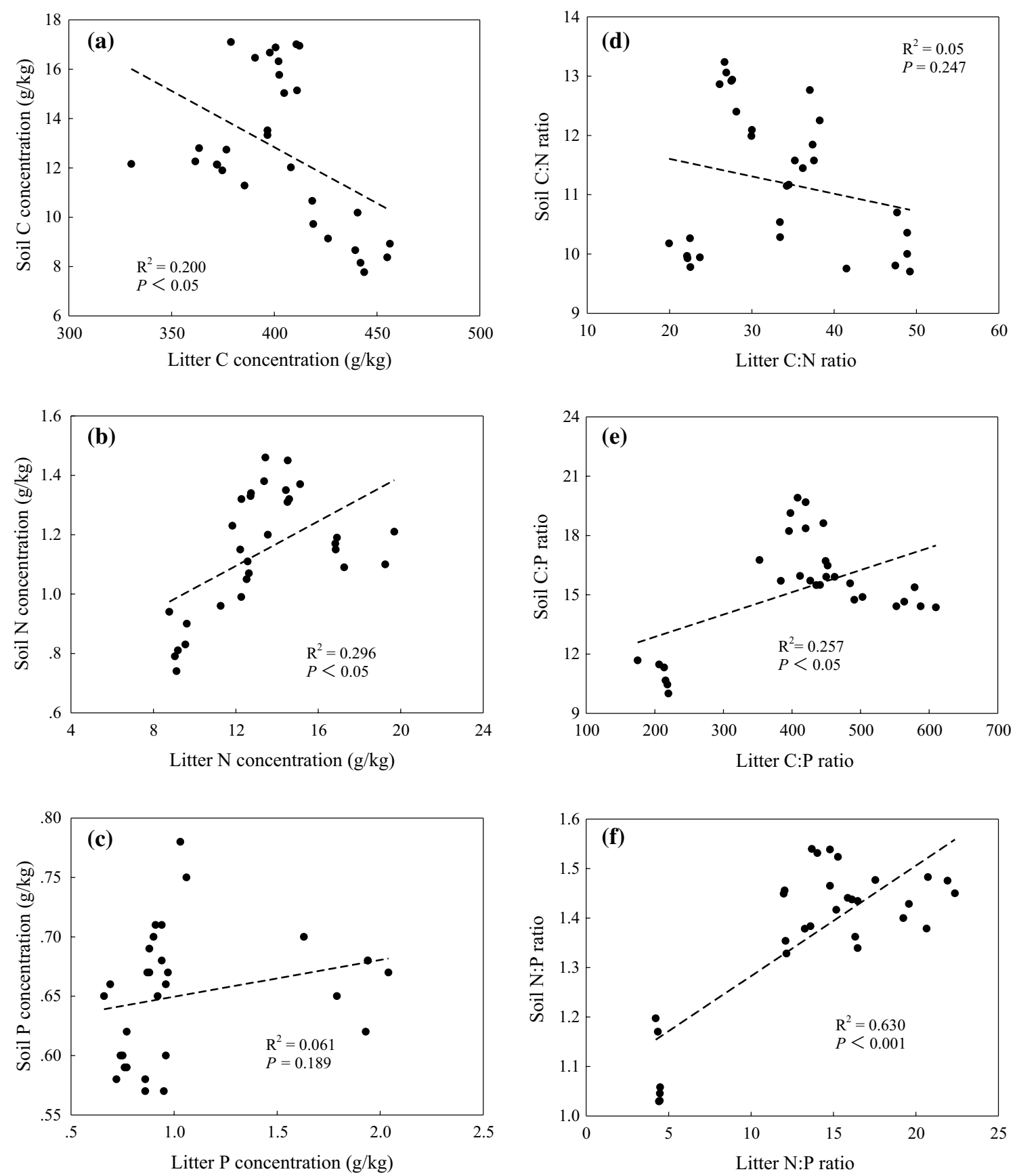

Fig. 6 Correlations between litter and soil C:N:P stoichiometric characteristics at 0-20 $\mathrm{cm}$ soil depth by successional stages

Sophora viciifolia (Franch.) Skeels, a nitrogen-fixing plant and can utilize atmospheric $\mathrm{N}_{2}$. Thus, leaf $\mathrm{N}: P$ ratios in mid successional stage was higher than that in early grass stage and forest stage. Although leaf N:P ratios may effectively reflect $\mathrm{N}$ or $\mathrm{P}$ limitations, the importance of the $\mathrm{N}: \mathrm{P}$ ratios is mainly in its function as an indicator (Güsewell 2004). In addition, a fertilization experiment should be conducted in the near future to identify limiting nutrient factors and verify the conclusion from this study.

\section{The effect of successional stages on soil $\mathbf{C}, \mathbf{N}$ and $P$ concentrations and $\mathrm{C}: \mathrm{N}: \mathrm{P}$ stoichiometry}

Site restoration by vegetation changes physical, chemical and biological soil properties, especially the circulation of the three important nutrients $(\mathrm{C}, \mathrm{N}$ and $\mathrm{P})$ in the soil (Wei et al. 2009). Converting farmland to grassland and ultimately forestland had considerable effects in reducing erosion, improving ecological environments and 

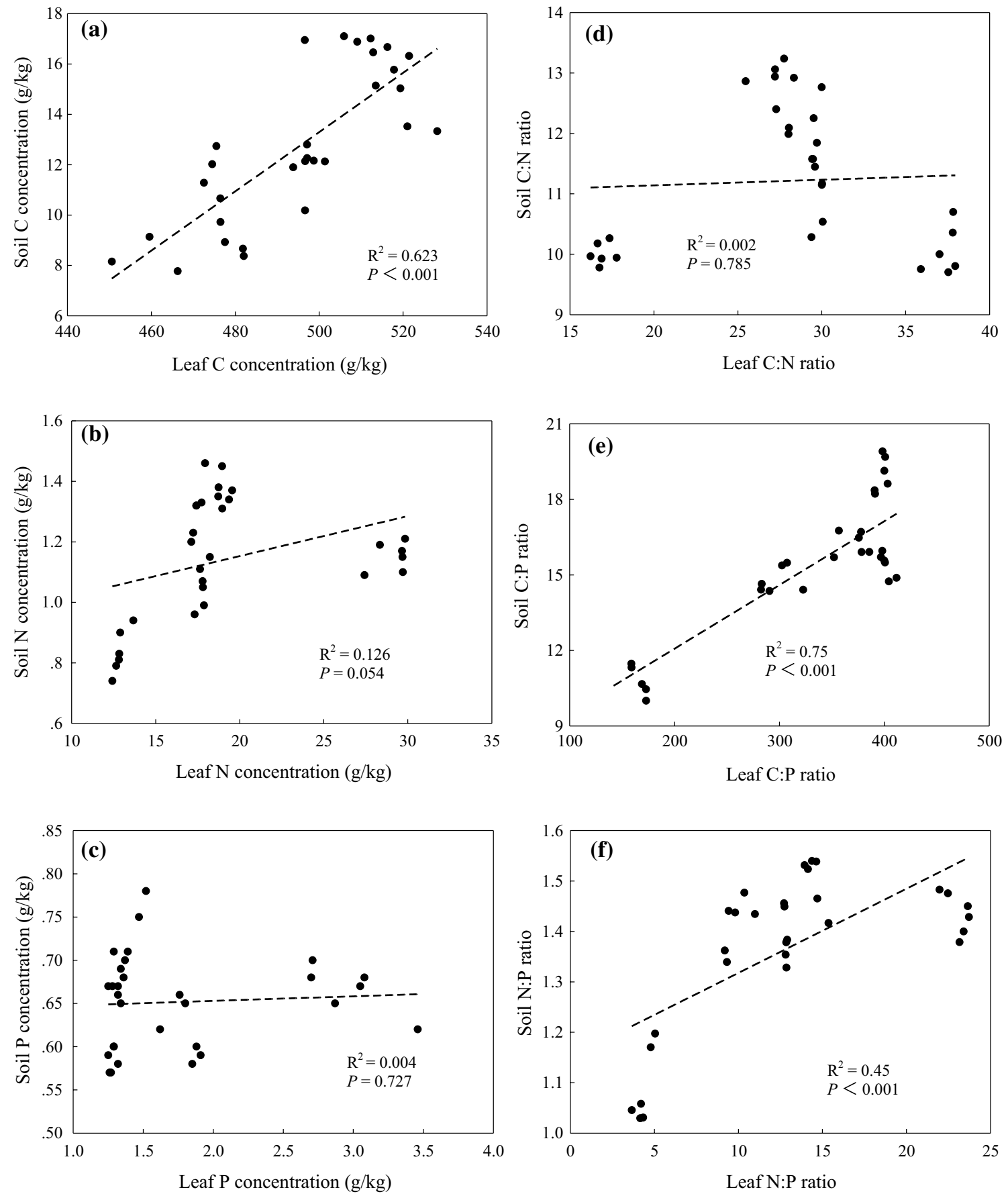

Fig. 7 Correlations between leaf and soil C:N:P stoichiometric characteristics at 0-20 $\mathrm{cm}$ soil depth by successional stages

enhancing soil quality (Garcia et al. 2002; Zheng 2006; Jiao et al. 2012). Long-term site restoration will increase soil nutrients, and significantly improve soil quality (Deng et al. 2013; Jiao et al. 2013; Zhao et al. 2015). Fu et al. (2010) observed that the restoration of vegetation increased $\mathrm{C}$ and $\mathrm{N}$ fixation because long-term site restoration reduced the loss of these elements caused by soil erosion. In this study, the results indicated that the soil C and $\mathrm{N}$ concentrations increased significantly over successional stages, this is consistent with the results of Deng et al. (2013). The main reason is that the composition, structure and level of the community gradually became more complex and diversified, and the enhanced activities of soil animals and microorganisms accelerated litter decomposition which increased the input of organic compounds, which in turn, led to high $\mathrm{C}$ and $\mathrm{N}$ concentrations. 
This study showed that $\mathrm{P}$ concentrations were different at different successional stages, decreasing from G1 and G2 stage and slowly increasing to the F1 stage, which is not in agreement with Zhang et al. (2015). In addition, C and $\mathrm{N}$ concentrations decreased with increasing depth, and in the top soil layer $(0-10 \mathrm{~cm})$ were higher than those in the lower layers, while soil $\mathrm{P}$ concentrations were relatively stable with increasing depth. This is mainly due to different sources of C, N and P. Soil C and N concentrations were affected by decomposition of the litter, and the nutrient return first occurs at the soil surface and leaches downward, while $\mathrm{P}$ concentration mainly influenced by weathering of parent materials and its low mobility, making it less variable (Wei et al. 2009).

$\mathrm{C}, \mathrm{N}$ and $\mathrm{P}$ are the three major elements of living organisms, and their ratios are an important trait of organisms and of ecosystems. Soil C:N:P ratio are an important index of organic matter composition, soil quality and nutrient supply capacity. A well-constrained global $\mathrm{C}: \mathrm{N}: \mathrm{P}$ ratio is $186: 13: 1$ at a depth of $10 \mathrm{~cm}(0-10 \mathrm{~cm}$ organic-rich soil) (Cleveland and Liptzin, 2007). In China, the average soil C:N:P ratio is 134:9:1 for surface soil (0-10 cm mineral soil) (Tian et al. 2010). In this study, the highest C:N:P ratio was 31.9:2.7:1.0 for the upper $10 \mathrm{~cm}$ organic-rich soil (Table 2), lower than the average for China and the global mean. This is due to the serious erosion in the study area which results in considerable surface carbon loss and low C:N:P ratios. Soil $\mathrm{C}: \mathrm{N}: \mathrm{P}$ ratios increased with successional stages. A possible reason is that the absorption and release of root system secretions changes $\mathrm{C}: \mathrm{N}: \mathrm{P}$ ratio; additionally, $\mathrm{N}$ and $\mathrm{P}$ released by litter decomposition in forestland affects the $\mathrm{C}: \mathrm{N}: \mathrm{P}$ ratio. Among these ratios, the $\mathrm{C}: \mathrm{N}$ ratio was a sensitive indicator of soil quality and could affect $\mathrm{C}$ and $\mathrm{N}$ cycling. In this study, there was a significant positive correlation between $\mathrm{C}$ and $\mathrm{N}$ concentrations $\left(\mathrm{R}^{2}=0.93\right)$, and the $\mathrm{C}: \mathrm{N}$ ratio was approximately 10.2 on the Loess Plateau, similar to the average value in China (10.0-12.0) (Tian et al. 2010) but lower than the global average (13.3) (Cleveland and Liptzin 2007). However, the result was higher than the reported by Liu et al. (2010) $(\mathrm{C}: \mathrm{N}=7.62)$. Tian et al. (2010) observed that $\mathrm{C}$ and $\mathrm{N}$ concentrations had wide spatial variability, whereas $\mathrm{C}: \mathrm{N}$ ratios were relatively stable. Our results are consistent with studies that show that $\mathrm{C}$ and $\mathrm{N}$ were closely related to plant structural components and that the $\mathrm{C}: \mathrm{N}$ ratio was relatively stable ratio in the processes of accumulation and consumption (Agren 2008). The soil N:P ratio may be used as an effective index of nutrient limitation (Tessier and Raynal 2003). The maximum value in this study of the N:P ratio was 2.7, lower than the 5.2 average in China (Tian et al. 2010). This is because the soil was alkaline and concentrations of soil $\mathrm{N}$ are low on the Loess Plateau. Therefore, plant growth was limited by $\mathrm{N}$ or by both $\mathrm{N}$ and $\mathrm{P}$. In addition, the N:P ratio was lower than the global value (5.9) (Cleveland and Liptzin 2007). The low ratio also shows that $\mathrm{N}$ concentrations were relatively low in the region. In addition, the N:P ratio in the climax forest stage was higher than in other stages; the reason is that from the annual grass to climax forest stage, the increase of $\mathrm{N}$ concentration was greater than that of $\mathrm{P}$ concentration.

\section{Relationship between soil and plant stoichiometry}

Plants sequester $\mathrm{C}$ through photosynthesis and gradually add it to the soil in the form of litter, while soil, as the medium of plant growth, provides all plant nutrients. The availability of soil nutrients determines the concentrations of chemical elements in plants. A better understanding was required to determine how nutrient cycles interact among plants, litter and soil during the successional stages in terrestrial ecosystems. The data presented here show a significant correlation between leaves and litter for C, $\mathrm{N}$ and $\mathrm{P}$ concentrations and their ratios, Lambers et al. (2010) reported correlations between $\mathrm{N}$ and P concentrations in soils and leaves in south-western Australia. Parfitt et al. (2005) also reported that soil $\mathrm{N}$ concentrations were positively correlated with leaf $\mathrm{N}$ concentration in temperate rain forests over three vegetation successional stages in New Zealand. Research shows that P concentration in leaves was closely related to $\mathrm{P}$ concentration in soil (Hedin 2004). However, other studies have reported that there were no relationships between soil and forest plants in terms of C, N and P concentrations (Ladanai et al. 2010; Yu et al. 2010). Significant positive correlations were also found between soil and leaves for C:N:P ratios in Australia's major native vegetation ecosystems (Bui and Henderson 2013), and Bell et al. (2014) found a strong correlation between soil and leaves for $\mathrm{C}: \mathrm{N}: \mathrm{P}$ ratios in semi-arid grassland ecosystems. In this study, the data indicate that leaf $\mathrm{N}$ and $\mathrm{P}$ concentrations have no correlations with soil $\mathrm{N}$ and $\mathrm{P}$ concentrations, a finding consistent with Ladanai et al. (2010). This is because of the absorption of mineral elements by plants and their transport, storage, and utilization area affected by many factors, including soil temperatures, water, microbial activities, and interspecific competition (Güsewell 2004; Reich and Oleksyn 2004). In addition, the species in the study region have long adapted to their habitat, and concentrations of $\mathrm{N}$ and $\mathrm{P}$ in leaves may be more influenced by the characteristics of the species themselves than by nutrients in the soil. However, there were close relations between leaf $\mathrm{N}: \mathrm{P}$ and $\mathrm{C}: \mathrm{P}$ ratios and soil N:P and C:P ratios. The results are consistent with those previous studies (Bui and Henderson 2013; Bell et al. 2014; Zeng et al. 2017). 
In general, correlations among leaf, litter and soil $\mathrm{C}, \mathrm{N}$ and $\mathrm{P}$ concentrations and $\mathrm{C}: \mathrm{N}: \mathrm{P}$ stoichiometry reflect, to some degree, the inheritance and co-invariance of nutrient concentrations. However, factors such as vegetation type and age, and soil depth result in differences in the correlations between leaf, litter and soil in terms of the $\mathrm{C}$, $\mathrm{N}$ and $\mathrm{P}$ concentrations and in the $\mathrm{C}: \mathrm{N}: \mathrm{P}$ stoichiometric characteristics, reflecting a flexible adaptation mechanism of plants to environmental change.

\section{Conclusion}

The results show that changes of leaf-litter-soil C, N and P concentrations and their stoichiometric characteristics were different with the successional stages. Leaf N:P ratios can be used to indicate nutritional limits for plant growth and this study found that plant growth in the grass stage was limited by $\mathrm{N}$, while in the shrub stage, growth was limited by $\mathrm{P}$, and in the forest stages, it was restricted by both of $\mathrm{N}$ and $\mathrm{P}$. There were significant correlations between leaf and litter nutrients $(P<0.05)$ and leaf $\mathrm{N}$ concentrations were significantly correlated with litter $\mathrm{N}$ concentrations $(P<0.05)$. However, there were no significant correlations between $\mathrm{N}$ and $\mathrm{P}$ concentrations in leaves and soil $(P=0.054$ and $P=0.727)$. The results provide a basis for the management of degraded ecosystems on the Chinese Loess Plateau.

Open Access This article is licensed under a Creative Commons Attribution 4.0 International License, which permits use, sharing, adaptation, distribution and reproduction in any medium or format, as long as you give appropriate credit to the original author(s) and the source, provide a link to the Creative Commons licence, and indicate if changes were made. The images or other third party material in this article are included in the article's Creative Commons licence, unless indicated otherwise in a credit line to the material. If material is not included in the article's Creative Commons licence and your intended use is not permitted by statutory regulation or exceeds the permitted use, you will need to obtain permission directly from the copyright holder. To view a copy of this licence, visit http://creativecommons.org/licenses/by/4.0/.

\section{References}

Agren GI (2008) Stoichiometry and nutrition of plant growth in natural communities. Annu Rev Ecol Evol Syst 39(1):153-170

An H, Shangguan ZP (2010) Leaf stoichiometric trait and specific leaf area of dominant species in the secondary succession of the Loess Plateau. Pol J Ecol 58:103-113

Bao SD (2000) Soil and agricultural chemistry analysis. China Agriculture Press, Beijing, pp 30-78 (in Chinese)

Bell C, Carrillo Y, Boot CM, Rocca JD, Pendall E, Wallenstein MD (2014) Rhizosphere stoichiometry: are C:N:P ratios of plants, soils, and enzymes conserved at the plant species-level? New Phytol 201:505-517

Broadbent EN, Zambrano AMA, Asner GP, Soriano M, Field CB, de Souza HR, Pena-Claros M, Adams RI, Dirzo R, Giles L (2014)
Integrating stand and soil properties to understand foliar nutrient dynamics during forest succession following slash-and-burn agriculture in the Bolivian Amazon. Plos One 9(2):e86042

Bui EN, Henderson BL (2013) C:N: P stoichiometry in Australian soils with respect to vegetation and environmental factors. Plant Soil 373:553-568

Chai YF, Liu X, Yue M, Guo JC, Wang M, Wan PC, Zhang XF, Zhang CG (2015) Leaf traits in dominant species from different secondary successional stages of deciduous forest on the Loess Plateau of northern China. Appl Veg Sci 18:50-63

Cleveland CC, Liptzin D (2007) C:N:P stoichiometry in soil: is there a "Redfield ratio" for the microbial biomass? Biogeochemistry $85: 235-252$

Davidson EA, Carvalho CJ, Figueira AM, Ishida FY, Ometto JP, Nardoto GB, Saba RT, Hayashi SN, Leal EC, Vieira IC, Martinelli LA (2007) Recuperation of nitrogen cycling in Amazonian forests following agricultural abandonment. Nature 447:995-998

Deng L, Wang KB, Chen ML, Shangguan ZP, Sweeney S (2013) Soil organic carbon storage capacity positively related to forest succession on the Loess Plateau, China. CATENA 110:1-7

Drenovsky RE, Richards JH (2004) Critical N:P values: predicting nutrient deficiencies in desert shrublands. Plant Soil 259(1-2):59-69

Du Y, Pan G, Li L, Hu Z, Wang X (2011) Leaf N/P ratio and nutrient reuse between dominant species and stands: predicting phosphorus deficiencies in Karst ecosystems, southwestern China. Environ Earth Sci 64:299-309

Elser J (2006) Biological stoichiometry: a chemical bridge between ecosystem ecology and evolutionary biology. Am Nat 168:S25-S35

Elser JJ, Sterner RW, Gorokhova E, Fagan WF, Markow TA, Cotner JB, Harrison JF, Hobbie SE, Odell GM, Weider LJ (2000) Biological stoichiometry from genes to ecosystems. Ecol Lett 3:540-550

Elser JJ, Acharya K, Kyle M, Cotner W, Makion W, Makion T, Wstts T, Hobbie S, Fagan W, Schade J, Hood J, Sterner RW (2003) Growth rate-stoichiometry couplings in diverse biota. Ecol Lett 6(10):936-943

Frouz J, Prach K, Pižl V, Háněl L, Starý J, Tajovský K, Materna J, Balík V, Kalčík J, Řehounková K (2008) Interactions between soil development, vegetation and soil fauna during spontaneous succession in post mining sites. Eur J Soil Biol 44(1):109-121

Fu XL, Shao MA, Wei XR, Horton R (2010) Soil organic carbon and total nitrogen as affected by vegetation types in Northern Loess Plateau of China. Geoderma 15:31-35

Garcia C, Hernandez T, Roldan A, Martin A (2002) Effect of plant cover decline on chemical and microbiological parameters under Mediterranean climate. Soil Biol Biochem 34:635-642

Güsewell S (2004) N:P ratios in terrestrial plants: variation and functional significance. New Phytol 164:243-266

Han WX, Fang JY, Guo DL, Zhang Y (2005) Leaf nitrogen and phosphorus stoichiometry across 753 terrestrial plant species in China. New Phytol 168:377-385

He JS, Wang L, Flynn DFB, Wang X, Ma W, Fang J (2008) Leaf nitrogen: phosphorus stoichiometry across Chinese grassland biomes. Oecologia 155:301-310

Hedin LO (2004) Global organization of terrestrial plant-nutrient interactions. 2004. PNAS 101:10849-10850

Huang W, Liu J, Wang Y, Zhou G, Han T, Li Y (2013) Increasing phosphorus limitation along three successional forests in southern China. Plant Soil 364:181-191

Jiao JY, Zhang ZG, Bai WJ, Jia YF, Wang N (2012) Assessing the ecological success of restoration by afforestation on the Chinese Loess Plateau. Restor Ecol 20:240-249

Jiao F, Zhong ZM, An SS, Yuan Z (2013) Successional changes in soil stoichiometry after land abandonment in Loess Plateau, China. Ecol Eng 58:249-254 
John R, Dalling JW, Harms KE, Yavitt JB, Stallard RF, Mirabello M, Hubbell SP, Valencia R, Navarrete H, Vallejo M (2007) Soil nutrients influence spatial distributions of tropical tree species. PNAS 104:864-869

Kang D, Guo Y, Ren C, Zhao F, Feng Y, Han X, Yang G (2014) Population structure and spatial pattern of main tree species in secondary Betula platyphylla forest in Ziwuling Mountains, China. Sci Rep 4:1-8

Kazakou E, Vile D, Shipley B, Gallet C, Garnier E (2006) Co-variations in litter decomposition, leaf traits and plant growth in species from a Mediterranean old-field succession. Funct Ecol 20(1):21-30

Koerselman W, Meuleman AFM (1996) The vegetation N:P ratio: a new tool to detect the nature of nutrient limitation. J Appl Ecol 33:441-1450

Ladanai S, Agren GI, Olsson BA (2010) Relationships between tree and soil properties in Picea abies and Pinus sylvestris forests in Sweden. Ecosystems 13:302-316

Laliberté E, Turner BL, Costes T, Pearse SJ, Wyrwoll K-H, Zemunik G, Lambers H (2012) Experimental assessment of nutrient limitation along a 2-million-year dune chronosequence in the south-western Australia biodiversity hotspot. J Ecol 100:631-642

Lambers H, Brundrett MC, Raven JA, Hopper SD (2010) Plant mineral nutrition in ancient landscapes: high plant species diversity on infertile soils is linked to functional diversity for nutritional strategies. Plant Soil 334:11-31

Letcher SG (2010) Phylogenetic structure of angiosperm communities during tropical forest succession. Proc R Soc B Biol Sci 277(1678):97-104

Liu X, Li FM, Liu DQ, Sun GJ (2010) Soil organic carbon, carbon fractions and nutrients as affected by land use in semi-arid region of Loess Plateau of China. Pedosphere 20:146-152

McGroddy ME, Baisden WT, Hedin LO (2008) Stoichiometry of hydrological C, N, and P losses across climate and geology: an environmental matrix approach across New Zealand primary forests. Global Biogeochem Cycles 22(1):GB1026

McIntyre S, Lavorel S, Landsberg J, Forbes TDA (1999) Disturbance response in vegetation-towards a global perspective on functional traits. J Veg Sci 10:621-630

Navas ML, Roumet C, Bellmann A, Laurent G, Garnier E (2010) Suites of plant traits in species from different stages of a Mediterranean secondary succession. Plant Biol 12:183-196

Nrcs USDA (1999) Soil taxonomy: a basic system of soil classification for making and interpreting soil surveys. Agricultural handbook 436, 2nd edn. U.S. Government Printing Office, Washington DC

Parfitt RL, Ross DJ, Coomes DA, Richardson SJ, Smale MC, Dahlgren RA (2005) N and P in New Zealand soil chronosequences and relationships with foliar $\mathrm{N}$ and $\mathrm{P}$. Biogeochemistry 75:305-328

Raevel V, Violle C, Munoz F (2012) Mechanisms of ecological succession: insights from plant functional strategies. Oikos 121:1761-1770

Rastetter EBR, Yanai RD, Thomas RQ, Vadeboncoeur MA, Fahey TJ, Fiak MC, Kwiatkowshi BL, Hamburg SP (2013) Recovery from disturbance requires resynchronization of ecosystem nutrient cycles. Ecol Appl 23(23):621-642

Reich PB, Oleksyn J (2004) Global patterns of plant leaf N and P in relation to temperature and latitude. PNAS 101:11001-11006

Richardson S, Peltzer D, Allen R, McGlone M, Parfitt R (2004) Rapid development of phosphorus limitation in temperate rainforest along the Franz Josef soil chronosequence. Oecologia 139:267-276

Roberts L, Stone R, Sugden A (2009) The rise of restoration ecology. Science 325(5940):555

Sardans J, Peñuelas J (2013) Tree growth changes with climate and forest type are associated with relative allocation of nutrients, especially phosphorus, to leaves and wood. Global Ecol Biogeogr 22(4):494-507

Schreeg LA, Santiago LS, Wright SJ, Turner BL (2014) Stem, root, and older leaf $\mathrm{N}: \mathrm{P}$ ratios are more responsive indicators of soil nutrient availability than new foliage. Ecology 95:2062-2068

Selmants PC, Hart SC (2008) Substrate age and tree islands influence carbon and nitrogen dynamics across a retrogressive semiarid chronosequence. Global Biogeochem Cycles 22(1):GB1021

Sparling GP, Schipper LA, Bettjeman W, Hill R (2003) Soil quality monitoring in New Zealand: practical lessons from a 6-year trial. Agric Ecosyst Environ 104(3):523-534

Takashima T, Hikosaka K, Hirose T (2004) Photosynthesis or persistence: nitrogen allocation in leaves of evergreen and deciduous Quercusspecies. Plant Cell Environ 27(8):1047-1054

Tessier JT, Raynal DJ (2003) Use of nitrogen to phosphorus ratios in plant tissue as an indicator of nutrient limitation and nitrogen saturation. J Appl Ecol 40(3):523-534

Tian HQ, Chen GS, Zhang C, Charles ASH, Jerry MM (2010) Pattern and variation of C:N:P ratios in China's soils: a synthesis of observational data. Biogeochemistry 98:139-151

Turrión MB, Glaser B, Solomon D, Ni A, Zech W (2000) Effects of deforestation on phosphorus poos in mountain soils of the Alay Range, Khyrgyzia. Biol Fertil Soils 31:134-142

Wang BK, Tang KL (1992) A study on temporal variation of reclamation on the Loess Plateau. J Soil Water Conserv 6(2):63-67 (in Chinese)

Wang KB, Shao RX, Shangguan ZP (2010) Changes in species richness and community productivity during succession on the Loess Plateau of China. Pol J Ecol 58(3):549-558

Wei XR, Shao MA, Fu XL, Horton R, Li Y, Zhang XC (2009) Distribution of soil organic $\mathrm{C}, \mathrm{N}$ and $\mathrm{P}$ in three adjacent land use patterns in the northern Loess Plateau, China. Biogeochemistry 96:149-162

Yu Q, Chen QS, Elser JJ, He NP, Wu HH, Zhang GM, Wu JG, Bai YF, Han XG (2010) Linking stoichiometric homoeostasis with ecosystem structure, functioning and stability. Ecol Lett 13:1390-1399

Zeng QC, Liu Y, Fang Y, Rentian M, Rattan L, An SS, Huang YM (2017) Impact of vegetation restoration on plants and soil C:N:P stoichiometry on the Yunwu Mountain Reserve of China. Ecol Eng 109:92-100

Zhang YW, Shangguan ZP (2016) The coupling interaction of soil water and organic carbon storage in the long vegetation restoration on the Loess Plateau. Ecol Eng 91:574-581

Zhang YW, Shangguan ZP (2018) Interaction of soil water storage and stoichiometrical characteristics in the long-term natural vegetation restoration on the Loess Plateau. Ecol Eng 116:7-13

Zhang W, Zhao J, Pan F, Li D, Chen H, Wang K (2015) Changes in nitrogen and phosphorus limitation during secondary succession in a karst region in southwest China. Plant Soil 391:77-91

Zhang YW, Deng L, Yan WM, Shangguan ZP (2016) Interaction of soil water storage dynamics and long-term natural vegetation succession on the Loess Plateau, China. CATENA 137:52-60

Zhao FZ, Di K, Han XH, Yang GH, Feng YZ, Ren GX (2015) Soil stoichiometry and carbon storage in long-term afforestation soil affected by understory vegetation diversity. Ecol Eng 74:415-422

Zheng FL (2006) Effect of vegetation changes on soil erosion on the Loess Plateau. Pedosphere 16:420-427

Zheng FL, Tang KL, Zhang K, Cha X, Bai H (1997) Relationship of eco-environmental change with natural erosion and artificially accelerated erosion. J China Geol 7(2):75-84 (in Chinese)

Zhou D, Zhao S, Zhu C (2012) The grain for green project induced land cover change in the Loess Plateau: a case study with Ansai County Shanxi Province, China. Ecol Indic 23:88-94

Publisher's Note Springer Nature remains neutral with regard to jurisdictional claims in published maps and institutional affiliations. 